\title{
Chapter 13 \\ Natural Succession of Wetland Vegetation in a Flood-Control Pond Constructed on Abandoned Farmland
}

\author{
Junko Morimoto, Susumu Goto, Akito Kuroyanagi, Motoko Toyoshima, \\ and Yuichiro Shida
}

\begin{abstract}
Can a flood-control basin be considered a component of green infrastructure (GI) with not only disaster prevention functions but also biodiversity conservation functions? We studied the succession of wetland vegetation in a floodcontrol basin constructed in a floodplain. The number of species composing the buried seeds depended on the depth of the soil layer, with shallower (recent) layers having more species. Plants germinated from buried seeds in deep (ancient) soil layers were small and difficult to identify based on morphology alone, but DNAbased analyses made it possible to identify these species. The occurrence of three species of Juncus and Cyperus in the peat layer that developed between 840 and 1215 years ago indicates that it is possible to regenerate wetland plants from the past if the buried seeds are well preserved and in good condition. The excavated section of the experimental site, which was set in part of the flood-control basin, received dispersed seeds from the surrounding agricultural land and contained more species than did the soil layer itself. The shallower the water depth was (the shallower the excavation depth), the greater the number of species that occurred. In addition, species with different life forms occurred depending on the water depth. More species occurred in the entire flood-control basin than in the experimental site. The factors that determined the type of plant community were years since excavation, water depth, and water quality. Finally, we discussed the management practices concerning the supply of propagules and the management of suitable habitats as essential factors for flood-control basins constructed on fallow land to function as GI.
\end{abstract}

J. Morimoto $(\triangle) \cdot$ A. Kuroyanagi $\cdot$ M. Toyoshima

Graduate School of Agriculture, Hokkaido University, Sapporo, Hokkaido, Japan

e-mail: jmo1219@for.agr.hokudai.ac.jp

S. Goto

Graduate School of Agricultural and Life Sciences, The University of Tokyo, The University of Tokyo Forests, Tokyo, Japan

Y. Shida

Wildlife Research Institute Co. Ltd., Sapporo, Hokkaido, Japan

(C) The Author(s) 2022

F. Nakamura (ed.), Green Infrastructure and Climate Change Adaptation,

Ecological Research Monographs, https://doi.org/10.1007/978-981-16-6791-6_13 
Keywords Buried seeds - Seed dispersal - Water depth - Succession · DNA barcoding $\cdot$ Field experiment

\subsection{Introduction}

The recent development of agricultural land has led to a global decline in wetland biodiversity (World Water Assessment Programme 2009; Zedler and Kercher 2005). This has led to concerns about the decline in biodiversity and ecosystem services in wetlands. On the other hand, in developed regions such as North America and the United Kingdom, the emergence of abandoned farmland has been reported since the beginning of the nineteenth century, and in Eastern Europe, Russia, and Latin America, this has occurred since the beginning of the twentieth century due to socioeconomic deterioration such as urbanization and industrialization and a decrease in the rural population (Baumann et al. 2011; Benayas and Bullock 2012; Kuemmerle et al. 2008). Agricultural land converted from wetlands by artificial draining is particularly prone to abandonment due to the high maintenance costs (Benjamin et al. 2005; Middleton 2003). Abandoned farmland that was once a wetland and adjacent to a river can be expected to serve as a flood-control basin and to restore wetland ecosystems (Morimoto and Shibata 2018). If these goals can be realized at the same time, it will be useful not only for disaster prevention but also for biodiversity conservation, making such sites beneficial green infrastructure (GI) from the perspective of improving the overall ecosystem services (Nakamura et al. 2020). In this chapter, we introduce a series of studies on the process of natural succession of wetland vegetation at a project site where a flood-control basin was established on abandoned farmland that had been a floodplain until it was developed into farmland in the twentieth century.

\subsection{Materials and Methods}

A flood-control basin (1150 ha) was constructed in a tributary of the Chitose River in northern Japan, Hokkaido $\left(42^{\circ} 55^{\prime} \mathrm{N}, 141^{\circ} 41^{\prime} \mathrm{E}\right.$, annual mean temperature of $7.2^{\circ} \mathrm{C}$, annual precipitation of $1005.6 \mathrm{~mm}$ ), which was farmland that had been used as paddy and dryland fields for approximately 10 years and then left fallow for 7 years (refer to Ishiyama et al. of Chap. 12 for the positioning of the flood-control basin and overall flood management). We chose the flood-control basin named "Maizuru Yusuichi" in Japanese as our study site (hereafter referred to as Crane Pond). The oldest topographic map of 1920 and later maps confirm that Crane Pond had been at the bottom of a lake until 1960. Carbon dating analysis indicated that the humus layer from $0 \mathrm{~m}$ to $0.3 \mathrm{~m}$ below the surface was deposited after 1739; the clay layer from $0.3 \mathrm{~m}$ to $1.2 \mathrm{~m}$ below the surface, after between 1190 and 1275 ; and the peat layer from $1.2 \mathrm{~m}$ to $1.5 \mathrm{~m}$ below the surface, after between 775 and 790 or 800 
(a)

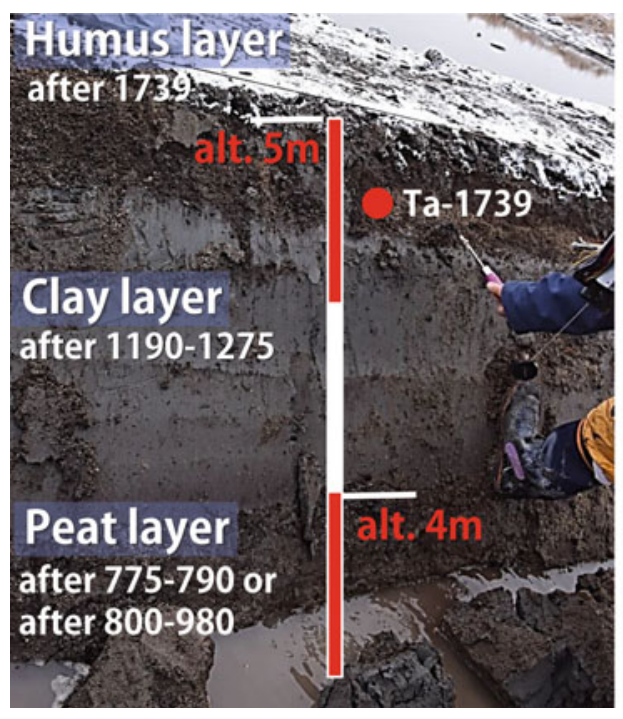

(b)
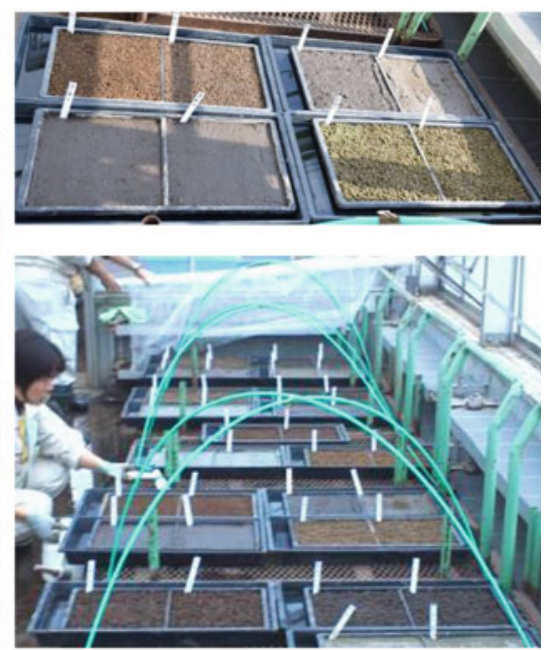

Fig. 13.1 Soil layers in Crane Pond (a) and assessment of the seed bank (b) Ta: volcanic deposit from Mt. Tarumae

and 980 (Fig. 13.1a). Therefore, it is assumed that this area, including Crane Pond, was a floodplain of a network of meandering rivers from the eighth or ninth century until, at the latest, the twentieth century, when the land was developed for farming. In this study area, before the construction of Crane Pond, an experiment was started to clarify the composition of the seed bank in the fallow farmland (2.2), and after the construction of Crane Pond, a survey of the naturally regenerated vegetation (2.3) was conducted.

\subsubsection{Experiment Started Before the Construction of Crane Pond: Exploring the Seed Bank Species in Fallow Farmland}

Soils from the humus, clay, and peat layers were collected in December 2014 and June 2015 from fallow farmland where Crane Pond was to later be constructed. The soil blocks were mixed by layer with 0.1 times the volume of water and loosened, and gravel and branches were removed. Two-centimeter-deep trays $\left(0.0576 \mathrm{~m}^{2}\right)$ were filled with soil that was sterilized by drying, and each layer of soil was spread out at a thickness of $1 \mathrm{~cm}$ (Fig. 13.1b). The soil was submerged in water so that the water surface coincided with the soil surface. The soil was covered with mesh to prevent seed contamination from outside. As a control, we also prepared 
trays sown with sterilized soil at a depth of $1 \mathrm{~cm}$. The germinating plants were observed until the development of new plants stopped (until the end of August for the soils collected in 2014 and until October for the soils collected in 2015). The plants were then grown until October 2016, and flowering and fruiting were confirmed. We identified the species by their morphological features except for three plants. These plants germinated from the peat layer as old as ca. 1000 years (hereafter, the ancient group). The size of the three plants was so small that we could not identify the species by morphological features alone, so chloroplast DNA information was used for species identification. First, we sampled collected leaves from the present group of Juncus decipiens (Buchenau) Nakai, Juncus tenuis Willd., Juncus bufonius L., and Juncus wallichianus Laharpe (which were candidate species based on their morphological features). Recently, DNA barcoding (barcode of life: BOL) has proven useful for species identification. For plants, a part of the sequence of the $r b c \mathrm{~L}$ gene is effective for species identification. In this study, we extracted DNA from the leaves of ancient and present plants, amplified the BOL region of the collected samples, and identified species based on sequence data. After aligning the sequences using MEGA ver. 7, we checked the corresponding sequences against the NCBI database.

\subsubsection{Experiment and Survey Started After the Construction of Crane Pond: Exploring the Vegetation that Regenerated Naturally}

Crane Pond was constructed between 2009 and 2014 and was put into service in April 2015. In July 2017, we randomly settled 51 quadrats $(2 \mathrm{~m} \times 2 \mathrm{~m})$ in Crane Pond, and the vegetation and aquatic environment was surveyed. Aquatic environmental parameters, including electrical conductivity $(\mathrm{EC}, \mu \mathrm{S} / \mathrm{cm})$, dissolved oxygen $(\mathrm{DO}, \%), \mathrm{pH}$, and depth $(\mathrm{cm})$, of surface water were measured. Plant communities were identified by TWINSPAN (two-way indicator species analysis) from the vegetation dataset. The relationships between plant communities and the water environment were analyzed by canonical correspondence analysis (CCA).

We built an experimental site $(0.17 \mathrm{ha})$ to observe the relationships between the regenerated species and water depth at the corner of Crane Pond (Fig. 13.2a). Excavation was carried out at three different depths (Fig. 13.2b, c). The water surface was at approximately the same level as the topmost ground surface (Fig. 13.2d). On the basis of the inaugural year of Crane Pond in 2015, we recorded the plant cover ratio of each species regenerated from 2015 to 2019. The succession over 5 years at three sections with different depths was monitored and recorded. 
13 Natural Succession of Wetland Vegetation in a Flood-Control Pond...

(a) Crane Pond, flood-control basin (ca. 200 ha)

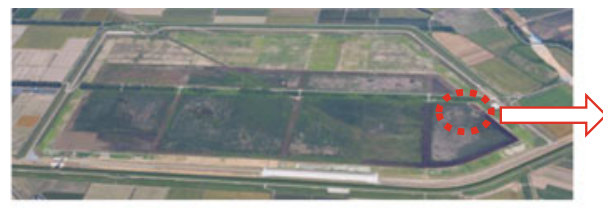

Field experiment site (FES, 0.17 ha)

(b) Overhead view of FES

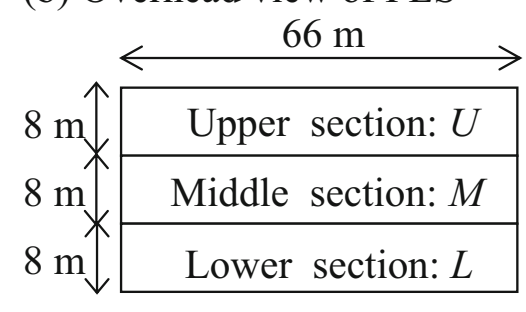

(c) Cross-sectional view of FES

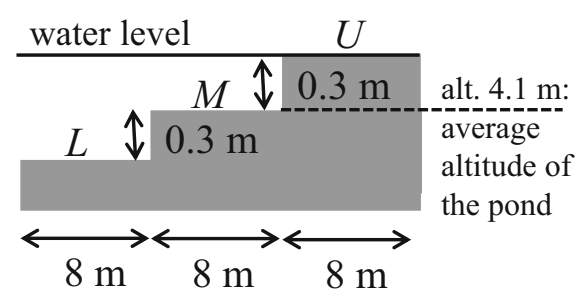

(d) Transition of the FES landscape over time
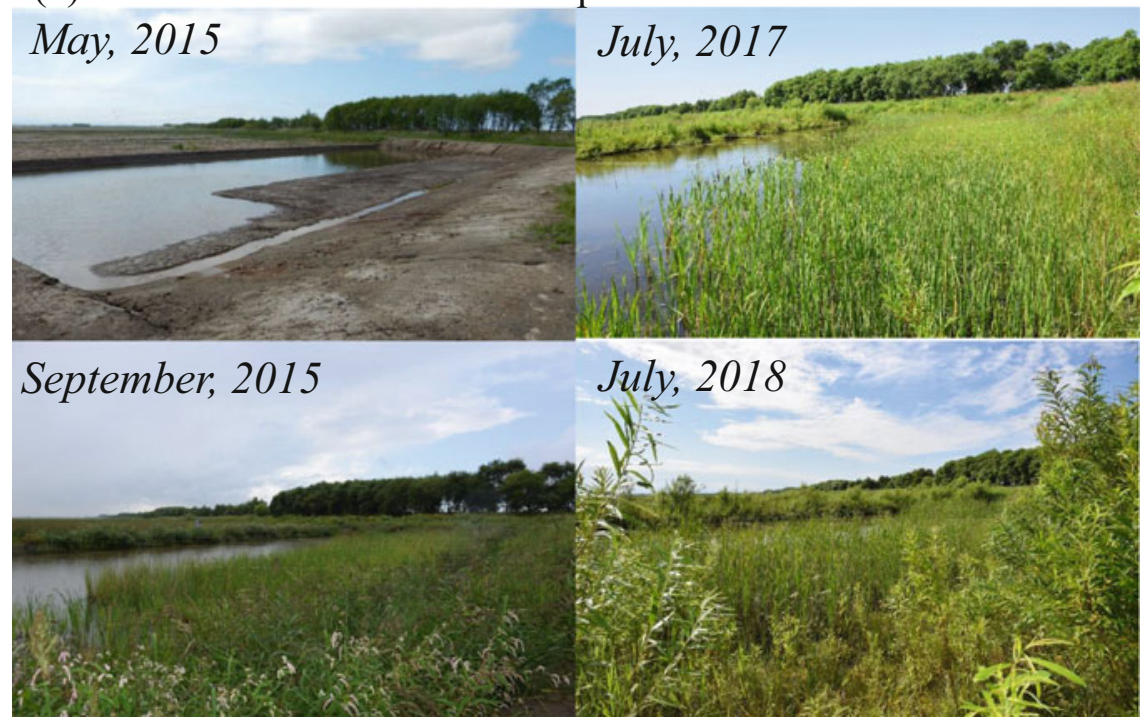

Fig. 13.2 Field experimental site built in a corner of a flood-control basin 


\subsection{Species Composition of Buried Seeds in Crane Pond}

\subsubsection{Species Identification by a Combination of Morphological and DNA Features}

Three plants that germinated from the peat layer were too small to identify, but the first one (P1) was assumed to be $J$. decipiens based on its morphological features. $r b c L$ DNA is used as a DNA barcoding region in plants (CBOL Plant Working Group 2009) because the diversity of $r b c L$ is conserved within a species but is likely to vary between species. The $r b c L$ DNA of many plant species is registered, which is advantageous in that a large amount of information is available but a disadvantage in that $r b c L$ genes are often shared among closely related species, as shown by the results of our analysis. According to a phylogenetic tree based on the $r b c L$ region (Tsubota et al. 2014), Juncus growing in wetlands in Hokkaido can be roughly classified according to the nucleotide sequence of this region. Therefore, we extracted DNA from leaves of P1 (Sample No. 4) and present plants of $J$. decipiens (Sample Nos. 1-3) and J. tenuis (Sample Nos. 5-6). After comparing the BOL sequences of the extracted DNA samples, at least five single-base substitutions occurred among $J$. decipiens and $J$. tenuis, and $\mathrm{P} 1$ had the same sequence as two $J$. tenuis plants collected in the southern part of Japan (Fig. 13.3). Then, we compared their sequences with those registered in the database of related species. We found that the sequences of Sample Nos. 1, 2, and 3 were identical to the sequence of $J$. decipiens (database ID number: KT695563) and that the sequences of Sample Nos. 4 (P1), 5, and 6 were identical to those of J. tenuis (KJ593488) and J. bufonius L. (KJ204357).

Since $J$. decipiens is abundant near the study site, we expected that P1 emerging from the peat layer might be this species before we performed the DNA analysis. However, the chloroplast DNA sequence clearly showed that P1 was not J. decipiens but rather J. tenuis or J. bufonius. J. tenuis and J. bufonius can be identified by the morphological features of their leaves (presence or absence of a membranous auricle in the leaf sheath). Finally, P1 was identified as J. tenuis because there was an auricle in the leaf sheath. Later, P2 and P3, which germinated from the

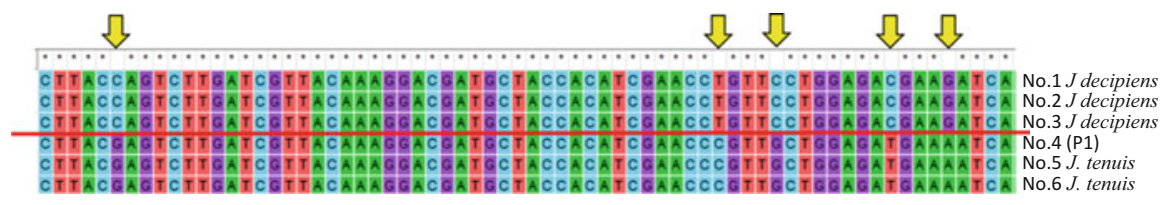

Fig. 13.3 Sequences of the $r b c L$ (BOL) region of the chloroplast genome for six plants. P1 (No. 4) germinated from the peat layer and was initially assumed to be Juncus decipiens. However, the sequence was different from that of this species (Nos. 1, 2, and 3) at several sites (yellow arrows). We found that the sequence of P1 (No. 4) was completely consistent with that of J. tenuis (Nos. 5 and 6) 
peat layer, were analyzed in the same way as P1, and the results were $100 \%$ consistent with J. wallichianus (registered as AB985730.1) collected in Hiroshima Prefecture. However, some of the sequences were different from those of the native J. wallichianus in Crane Pond, and further study is needed. Thus, the combination of morphological and DNA analyses showed the possibility of reliable species identification of small plants, which are difficult to identify based on morphological information alone.

\subsubsection{Species Composition in Each Soil Layer from Different Depths}

All plants except the three plants germinated from the peat layer were identified by morphological features alone. All the germinated species were present, and one of them, Sparganium erectum L. var. coreanum (H. Lév.) H. Hara, was a nearthreatened species (Table 13.1). The number of species and plants was the highest in the latest layer of humus and was lower in older layers of clay and peat (Fig. 13.4). However, each layer produced unique species (Table 13.1). The planned elevation of Crane Pond (4.1 m above sea level) is comparable to the height of the clay layer, meaning that the humus layer containing the largest number of species has been stripped off and has spread out into the depression inside Crane Pond. Thus, the main contribution of buried seeds to natural succession in Crane Pond was assumed to be buried seeds from the humus and clay layers. In addition, notably, three species of Juncus and Cyperus germinated from the peat layer as old as ca. 1000 years old.

The result that the latest layer produced the most abundant species and plants coincides with the view that the germination ratio of seeds declines over time after production and that the seed longevity of most species is less than 5 years

Table 13.1 Number of plants from each soil layer

\begin{tabular}{l|c|c|l|l|l|l|l}
\hline & \multicolumn{2}{|l|}{} & & & \multicolumn{2}{l}{$\left(\mathrm{m}^{-2}\right)$} \\
\hline & \multicolumn{2}{|l|}{ Humus $(N=16)$} & \multicolumn{2}{l|}{ Clay $(N=14)$} & \multicolumn{2}{l}{ Peat $(N=32)$} \\
\hline & Mean & SD & Mean & SD & Mean & SD \\
\hline Cyperus difformis & 0.0 & 0.00 & 0.0 & 0.00 & 0.5 & 3.02 \\
\hline Juncus bufonius & 1.1 & 4.1 & 0.0 & 0.00 & 0.0 & 0.00 \\
\hline Juncus decipiens & 316.8 & 509.5 & 0.0 & 0.00 & 0.0 & 0.00 \\
\hline Juncus prismatocarpus & 9.8 & 25.2 & 0.0 & 0.00 & 1.6 & 6.7 \\
\hline Juncus tenuis & 0.0 & 0.00 & 0.0 & 0.00 & 0.5 & 3.02 \\
\hline Juncus wallichianus & 10.9 & 20.5 & 0.0 & 0.00 & 0.0 & 0.00 \\
\hline Schoenoplectiella hondoensis & 5.4 & 11.5 & 0.0 & 0.00 & 0.0 & 0.00 \\
\hline Schoenoplectiella triangulata & 0.0 & 0.00 & 1.2 & 4.47 & 0.0 & 0.00 \\
\hline Schoenoplectus tabernaemontani & 55.3 & 78.6 & 1.2 & 4.5 & 0.0 & 0.00 \\
\hline Sparganium erectum & 2.2 & 8.2 & 0.0 & 0.00 & 0.0 & 0.00 \\
\hline
\end{tabular}




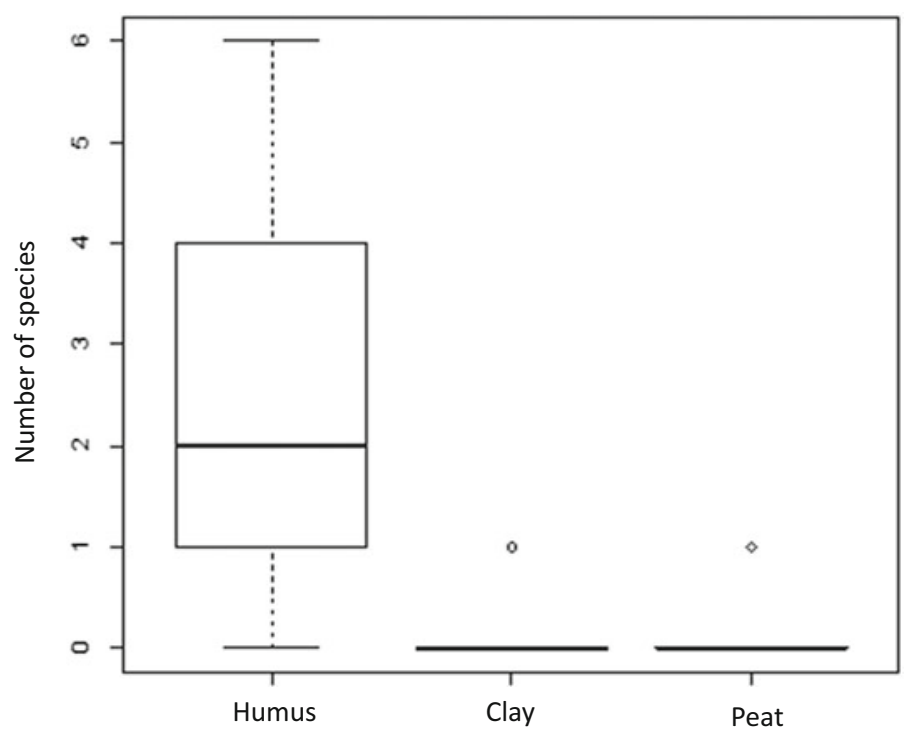

Fig. 13.4 Number of species $\left(/ 0.025 \mathrm{~m}^{2}\right)$ from each soil layer. Open circles indicate outliers; the top, center, and bottom lines of each box indicate the third, second, and first quartiles, respectively. The horizontal lines above and below the box indicate the maximum and minimum values, respectively (refer to Fig. 13.1 for the position of each soil layer)

(Baskin and Baskin 2014). Long-lived seeds of more than 5 years have been reported occasionally (e.g., 100 years in Malvaceae, 80 years in Leguminosae, and 77 years in Lamiaceae), but reports of long-lived seeds exceeding 1000 years are very rare (Oga 1951). The germination of three species of Juncus and Cyperus from the ancient peat layer indicates their uniqueness. The conditions under which seeds can be stored for long periods of time are said to be cool, mildly alternating temperatures, and low oxygen (Baskin and Baskin 2014). These conditions might be easily possible in Crane Pond, which was the bottom of a lake until land reclamation for agriculture in the 1960s.

\subsection{Natural Succession in Crane Pond}

\subsubsection{Features of Species Generated from Different Water Depths}

Plant succession at the field experimental site is shown in Table 13.2. The number of species was higher than that contained in the soil layers (Table 13.1). This indicates that the number of samples was limited for the survey of buried seeds and that propagules dispersed by wind, water, and birds from surrounding agricultural land 
contributed to plant establishment at the experimental site. In addition, it was found that plants were first established in the shallow water stage and that plants with different life forms were established depending on the water depth (Table 13.2). Annual plants that emerged in the first year did not appear after the second year. The occurrence of alien species was negligible.

Hygrophytes and emergent macrophytes mainly emerged in the upper and middle sections half a year after the excavation; however, it took 3 years for plant establishment in the lower section, and floating-leaved macrophytes and submerged macrophytes emerged. Hygrophytes and emergent macrophytes are mainly dispersed by wind, whereas floating-leaved macrophytes and submerged macrophytes are mainly dispersed by water or birds (Kameyama and Ohara 2007; Mikulyuk and Nault 2009; Phartyal et al. 2018). It can be considered that the vegetation recovery in the lower section was slower than that in the upper and middle sections because the opportunities for dispersal by water inflow and bird visits to Crane Pond were more limited than those by wind.

Hygrophyte species that occurred in the first year were annual plants dependent upon disturbance (Euliss et al. 2004). Many of them were presumed to have not occurred after the second year because flood disturbance did not occur in the field experimental site. Human or natural disturbance is necessary to sustain disturbancedependent species.

Mesophytes, including alien species, disappeared by the second year of the project, which means that there is no need to worry about alien species of mesophytic plants invading the water body as long as the wet environment is maintained.

\subsubsection{Years from Excavation, Water Depth, and Water Quality Determine the Plant Community}

From the field experiments, it was found that the native species occur in order from shallow to deep water, and their life forms depend on the water depth. Next, when we looked at plant establishment throughout the entire Crane Pond, 26 native species (including five rare species) appeared, which is more than that in the experimental site, and no exotic species appeared (Kuroyanagi et al. 2019). The 13 unique species that did not appear in the experimental site and in the seed bank appeared in Crane Pond (Fig. 13.5). Crane Pond is vast and includes areas where the water was deeper than that at the experimental site, and because of the large amount of incoming water and waterfowl flights, it was suitable for the establishment of floating-leaved, free-floating aquatic, and submerged macrophytes. Among the species that have contributed to vegetation recovery in Crane Pond, there are three species that are the same as those found in the buried seeds. Wetland vegetation in Crane Pond regenerated mainly from propagules supplied from outside Crane Pond, but buried 
Table 13.2 Changes in plant species observed at the field experimental site

\begin{tabular}{|c|c|c|c|c|c|c|c|c|c|}
\hline Site ${ }^{a}$ & $\begin{array}{l}\text { Life } \\
\text { form }^{b}\end{array}$ & $\begin{array}{l}\text { Life } \\
\text { history }\end{array}$ & $\begin{array}{l}\text { Red list or } \\
\text { Blue list }{ }^{\mathrm{d}}\end{array}$ & Species & \multicolumn{5}{|c|}{ The year of presence } \\
\hline & & & & & 2015 & 2016 & 2017 & 2018 & 2019 \\
\hline \multirow[t]{31}{*}{$\mathrm{U}$} & \multirow[t]{2}{*}{$m$} & A & & Persicaria longiseta & - & & & & \\
\hline & & A,B & $\checkmark$ & Gnaphalium uliginosum & $\bullet$ & & & & \\
\hline & \multirow[t]{3}{*}{ m-wet } & $\mathrm{P}$ & $\checkmark$ & Trifolium spp. & • & & & & \\
\hline & & $\mathrm{P}$ & $\checkmark$ & Rudbeckia laciniata & & - & & & \\
\hline & & $\mathrm{P}$ & & Juncus tenuis & & & - & - & - \\
\hline & \multirow[t]{15}{*}{$h$} & $\mathrm{~A}$ & & $\begin{array}{l}\text { Persicaria sagittata var. } \\
\text { sibirica }\end{array}$ & - & - & $\bullet$ & $\bullet$ & - \\
\hline & & A & & $\begin{array}{l}\text { Echinochloa crus-galli } \\
\text { var. crus-galli }\end{array}$ & - & $\bullet$ & & & • \\
\hline & & A & & $\begin{array}{l}\text { Echinochloa crus-galli } \\
\text { var. aristata }\end{array}$ & • & & - & & \\
\hline & & A & & Cyperus difformis & - & & • & & \\
\hline & & A & $* * *$ & $\begin{array}{l}\text { Persicaria foliosa var. } \\
\text { paludicola }\end{array}$ & • & & & & • \\
\hline & & $\mathrm{A}$ & & Persicaria lapathifolia & - & & & & \\
\hline & & A & & Juncus bufonius & - & & & & \\
\hline & & $\mathrm{A}$ & & Persicaria muricata & - & & & & \\
\hline & & $\mathrm{P}$ & & Lythrum salicaria & - & - & & & - \\
\hline & & $\mathrm{P}$ & $\checkmark$ & Phalaris arundinacea & - & & $\bullet$ & & - \\
\hline & & $\mathrm{P}$ & $* * *$ & Carex capricornis & & - & • & • & \\
\hline & & $\mathrm{T}$ & & Salix udensis & • & - & • & • & - \\
\hline & & $\mathrm{T}$ & & Salix schwerinii & - & & & & - \\
\hline & & $\mathrm{T}$ & & $\begin{array}{l}\text { Salix triandra subsp. } \\
\text { nipponica }\end{array}$ & & & • & $\bullet$ & • \\
\hline & & $\mathrm{T}$ & & Salix integra & & & & • & \\
\hline & \multirow[t]{9}{*}{$e, h$} & $\mathrm{~A}$ & $* *$ & Monochoria korsakowii & $\bullet$ & & & & \\
\hline & & $\mathrm{P}$ & & $\begin{array}{l}\text { Alisma } \\
\text { plantago-aquatica var. } \\
\text { orientale }\end{array}$ & • & - & • & • & • \\
\hline & & $\mathrm{P}$ & & Juncus decipiens & - & • & • & $\bullet$ & - \\
\hline & & $\mathrm{P}$ & & Scirpus radicans & - & $\bullet$ & $\bullet$ & - & - \\
\hline & & $\mathrm{P}$ & & Juncus wallichianus & $\bullet$ & $\bullet$ & • & - & • \\
\hline & & $\mathrm{P}$ & & $\begin{array}{l}\text { Schoenoplectiella } \\
\text { triangulata }\end{array}$ & - & - & - & • & \\
\hline & & $\mathrm{P}$ & & $\begin{array}{l}\text { Juncus prismatocarpus } \\
\text { subsp. leschenaultii }\end{array}$ & - & • & & & \\
\hline & & $\mathrm{P}$ & & Alisma canaliculatum & $\bullet$ & & $\bullet$ & & \\
\hline & & $\mathrm{P}$ & & Cicuta virosa & & & & $\bullet$ & - \\
\hline & \multirow[t]{2}{*}{$e$} & A & & Schoenoplectus hotarui & • & • & & & \\
\hline & & $\mathrm{P}$ & & $\begin{array}{l}\text { Schoenoplectus } \\
\text { tabernaemontani }\end{array}$ & - & - & • & • & • \\
\hline
\end{tabular}

(continued) 
Table 13.2 (continued)

\begin{tabular}{|c|c|c|c|c|c|c|c|c|c|}
\hline \multirow[t]{2}{*}{ Site $^{\mathrm{a}}$} & \multirow[t]{2}{*}{$\begin{array}{l}\text { Life } \\
\text { form }^{b}\end{array}$} & \multirow[t]{2}{*}{\begin{tabular}{|l} 
Life \\
history
\end{tabular}} & \multirow[t]{2}{*}{$\begin{array}{l}\text { Red list or } \\
\text { Blue list }^{\mathrm{d}}\end{array}$} & \multirow[t]{2}{*}{ Species } & \multicolumn{5}{|c|}{ The year of presence } \\
\hline & & & & & 2015 & 2016 & 2017 & 2018 & 2019 \\
\hline & & $\mathrm{P}$ & & Typha latifolia & - & - & • & • & • \\
\hline & & $\mathrm{P}$ & & Zizania latifolia & - & - & • & • & \\
\hline & & $\mathrm{P}$ & & $\begin{array}{l}\text { Bolboschoenus fluviatilis } \\
\text { subsp. yagara }\end{array}$ & $\bullet$ & $\bullet$ & $\bullet$ & & \\
\hline & & $\mathrm{P}$ & $*$ & Sparganium erectum & • & - & & & \\
\hline & & $\mathrm{P}$ & & Schoenoplectus triqueter & • & & $\bullet$ & $\bullet$ & \\
\hline & & $\mathrm{P}$ & & Eleocharis mamillata & & • & $\bullet$ & $\bullet$ & $\bullet$ \\
\hline & & $\mathrm{P}$ & & $\begin{array}{l}\text { Bolboschoenus } \\
\text { koshevnikovii }\end{array}$ & & - & & & \\
\hline & $f r$ & A & & $\begin{array}{l}\text { Lemna aoukikusa subsp. } \\
\text { aoukikusa }\end{array}$ & & & - & & \\
\hline & $f l$ & A & & Trapa japonica & & & & & • \\
\hline & $s, f$ & $\mathrm{P}$ & & $\begin{array}{l}\text { Potamogeton octandrus } \\
\text { var. octandrus }\end{array}$ & & - & & & \\
\hline \multirow[t]{5}{*}{$\mathrm{M}$} & \multirow[t]{2}{*}{$e$} & $\mathrm{P}$ & & Typha latifolia & & & & $\bullet$ & $\bullet$ \\
\hline & & $\mathrm{P}$ & & Zizania latifolia & & & & & $\bullet$ \\
\hline & $f l$ & A & & Trapa japonica & & & & $\bullet$ & $\bullet$ \\
\hline & $s, f$ & $\mathrm{P}$ & & $\begin{array}{l}\text { Potamogeton octandrus } \\
\text { var. octandrus }\end{array}$ & & & & • & $\bullet$ \\
\hline & $f r, s$ & $\mathrm{P}$ & $*$ & Utricularia japonica & & & & & $\bullet$ \\
\hline \multirow[t]{4}{*}{$\mathrm{L}$} & $f$ & A & & Trapa japonica & & & & $\bullet$ & $\bullet$ \\
\hline & $f r$ & A & & $\begin{array}{l}\text { Lemna aoukikusa subsp. } \\
\text { aoukikusa }\end{array}$ & & & & & $\bullet$ \\
\hline & $s, f l$ & $\mathrm{P}$ & & $\begin{array}{l}\text { Potamogeton octandrus } \\
\text { var. octandrus }\end{array}$ & & & & • & • \\
\hline & $f r, s$ & $\mathrm{P}$ & $*$ & Utricularia japonica & & & & & $\bullet$ \\
\hline
\end{tabular}

${ }^{\text {a }} U$ upper section, $M$ middle section, $L$ lower section

${ }^{\mathrm{b}}$ Life form is identified for wetland plants and others based on the description from picture books. $h$ hygrophyte, $e$ emergent macrophyte, $f$ floating-leaved macrophyte, $f r$ free-floating aquatic macrophyte, $s$ submerged macrophyte, $m$ mesophyte, $m$-wet methophyte that can live in a wet environment

${ }^{\mathrm{c}} A$ annual plant, $B$ biennial plant, $P$ perennial plant, $T$ tree

${ }^{\mathrm{d}}$ We denoted the species categories of national (Japan) and regional (Hokkaido Prefecture) red lists according to Japanese Red lists (Ministry of Environment of Japan, 2017) and Hokkaido Red lists (Hokkaido Prefecture, 2001, 2017, 2018), respectively. The categories of Japanese Red lists (2017) are EN (Endangered), VU (Vulnerable), and NT (Near Threatened). The categories of Hokkaido Red lists (2001) are EN (Endangered), VU (Vulnerable), and R (Rare). We classified species as alien species according to Hokkaido Blue lists (Hokkaido Prefecture, 2010). ***, VU/R; **, NT/VU; *, NT/R; $\checkmark$, blue list 


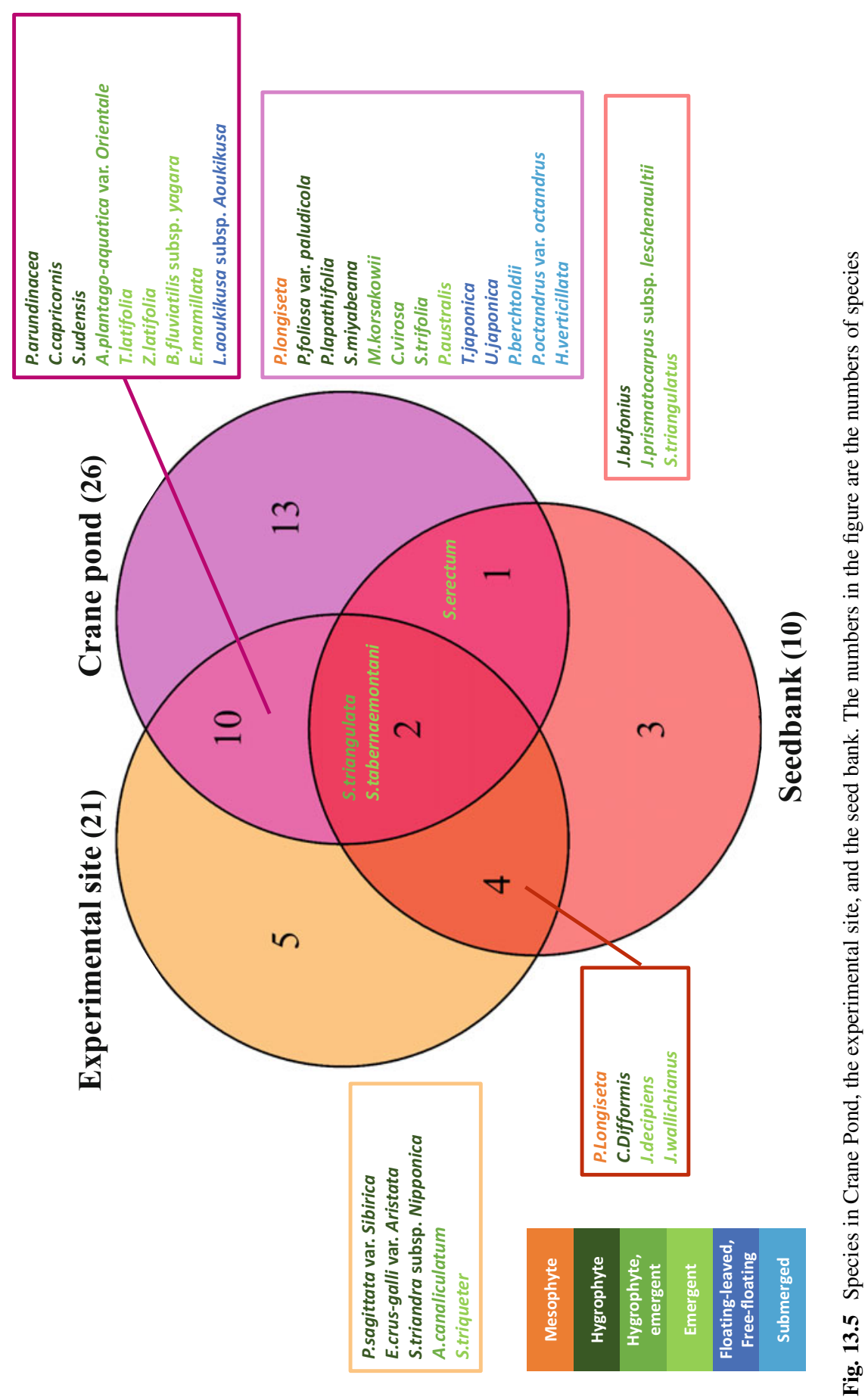




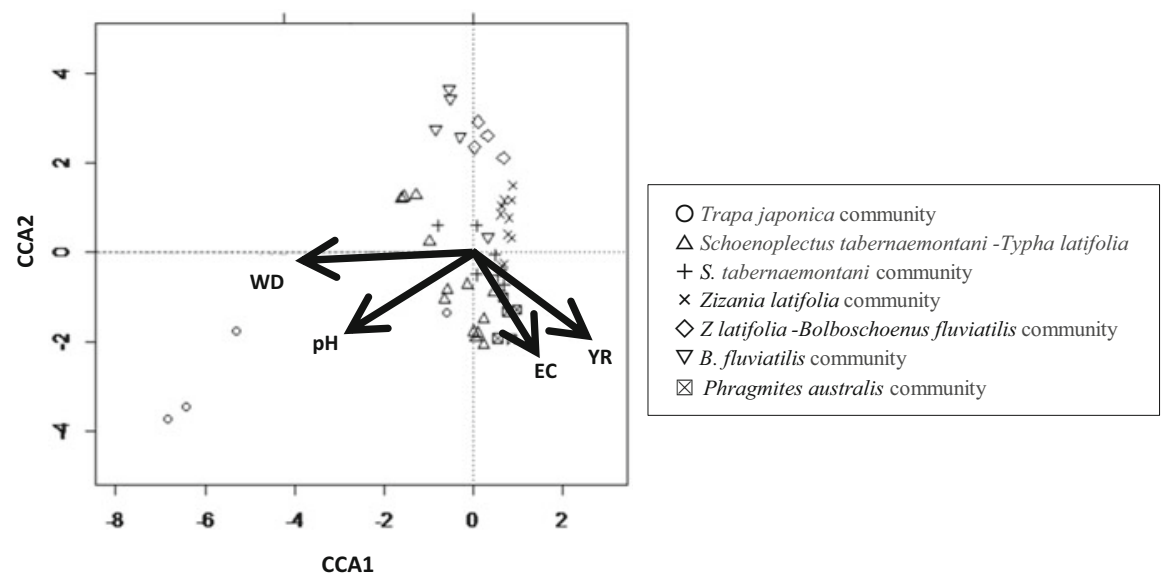

Fig. 13.6 Relationships between plant communities and environmental factors. WD, water depth; YR, years since excavation; EC, electrical conductivity

seeds also played an important role in maintaining the species diversity of wetland vegetation in Crane Pond.

Six types of plant species communities were present: the Schoenoplectus tabernaemontani-Typha latifolia community, Schoenoplectus tabernaemontani community, Zizania latifolia community, Z. latifolia-Bolboschoenus fluviatilis community, B. fluviatilis community, and Phragmites australis community. The factors characterizing the habitat of plant communities were the time since excavation, water depth, and water quality (Fig. 13.6). In Crane Pond, where 37 years have passed since excavation, floating-leaved Trapa japonica has developed in deeper water, and emergent macrophytes such as Zizania latifolia and Phragmites australis have developed in shallower water. These results coincide with those of the experimental site. Eutrophication, expressed as increasing EC, tended to increase with years since excavation, and the transition to a reed (Trapa japonica) community was observed (Fig. 13.6). These results suggest that creating various depths of water inside a flood-controlled basin and controlling the progress of eutrophication are effective in maintaining the various wetland species and plant communities.

\subsection{Implications for Management of the Flood-Control Basin as GI}

There are many cases in which past wetland vegetation did not recover on fallow land (e.g., González et al. 2017; Sheldon et al. 2016). The initial requirements for the recovery of wetland vegetation are the supply of propagules of wetland plants (Bischoff et al. 2009; Vécrin et al. 2002) and a suitable habitat for their 
growth and reproduction (Morimoto et al. 2017; Weiher and Keddy 1995). What kind of management is necessary for a flood-control basin built on fallow land to function as GI, conserve wetland ecosystems, and control floods? We will discuss the management of the supply of propagules and the management of suitable habitats.

\subsubsection{Management of the Supply of Propagules}

We can expect two types of propagules in the flood-control basin, buried and dispersed propagules. Our study showed that buried seeds were preserved even in the deep ancient soil layers that had accumulated at the time of the floodplain, and these seeds can be utilized for wetland restoration. A persistent seed bank functions as a gene pool (Bossuyt and Honnay 2008). Effective utilization of soil containing ancient seeds will enable wetland restoration considering genetic diversity. On the other hand, propagule dispersal from the surroundings is an essential requirement for the restoration of wetland vegetation with high diversity because the species that can be supplied from buried seeds are limited. Waterways running in an agricultural landscape function as refuges for wetland plants (Toyoshima et al. 2020). It is important to conserve these waterways as propagule sources for flood-control basins established in agricultural landscapes by organic farming or farming with low levels of agricultural chemicals.

\subsubsection{Management for Suitable Habitat}

Excavation is a general practice for the construction of flood-control basins, and the removal of surface soil is a general practice for the restoration of wetlands. Both practices have a similar effect on suitable habitat creation. Such practices increase the number of vacant sites, which permit the establishment of new plants (Klimkowska et al. 2010), decrease soil nutrients (Verhagen et al. 2001), increase the water level (Galatowitsch and van der Valk 1996; Klimkowska et al. 2010), and increase flood frequency (Hölzel and Otte 2004). However, both excavation and the removal of the surface soil will decrease the availability of seed banks in the soil, making these practices not a good idea if the propagule source is limited in the vicinity. Instead, it is recommended that drainage facilities be removed to raise the groundwater level and create a waterlogged environment to promote the effective use of seed banks (Morimoto and Shibata 2018). The reuse of topsoil removed during excavation can be an option, although keeping the waterlogged environment is a requirement to prevent the domination of alien species. In addition, a design that creates a variety of depths within the flood-control basin would contribute to the species diversity of plants, as it would promote the establishment of plants with different life forms suitable for different depths. After the construction of a floodcontrol basin, controlling the eutrophication of water from the surrounding farmland 
and removing the sediment soils to maintain the water depth should be effective for the conservation of wetland vegetation. Ideally, river floods should be large enough to occasionally wash away the accumulated sediment in a flood-control basin.

One of the important attractions of GI is that it does not require or reduces maintenance costs. Even before the construction of the flood-control basin, it is essential to select a site and design a structure that aims to regenerate and maintain the wetland ecosystem by natural processes for the flood-control basin to function as GI.

Acknowledgments We appreciate Ms. Mitsuko Goto (The Asian Natural Environmental Science Center, The University of Tokyo) for carrying out the DNA analyses and Dr. Kazuo Yabe (Sapporo City University) for providing advice on the succession of wetland vegetation.

\section{References}

Baskin CC, Baskin JM (2014) Seeds: ecology, biogeography, and, evolution of dormancy and germination. Academic Press, San Diego, CA

Baumann M, Kuemmerle T, Elbakidze M, Ozdogan M, Radeloff VC, Keuler NS, Prishchepov AV, Kruhlov I, Hostert P (2011) Patterns and drivers of post-socialist farmland abandonment in Western Ukraine. Land Use Policy 28:552-562

Benayas JMR, Bullock JM (2012) Restoration of biodiversity and ecosystem services on agricultural land. Ecosystems 15:883-899

Benjamin K, Domon G, Bouchard A (2005) Vegetation composition and succession of abandoned farmland: effects of ecological, historical and spatial factors. Landsc Ecol 20:627-647

Bischoff A, Warthemann G, Klotz S (2009) Succession of floodplain grasslands following reduction in land use intensity: the importance of environmental conditions, management and dispersal. J Appl Ecol 46:241-249

Bossuyt B, Honnay O (2008) Can the seed bank be used for ecological restoration? An overview of seed bank characteristics in European communities. J Veg Sci 19:875-884

CBOL Plant Working Group (2009) A DNA barcode for land plants. Proc Natl Acad Sci U S A 106(31):12794-12797

Euliss NH, LaBaugh JW, Fredrickson LH, Mushet DM, Laubhan MK, Swanson GA, Winter TC, Rosenberry DO, Nelson RD (2004) The wetland continuum: a conceptual framework for interpreting biological studies. Wetlands 24:448-458

Galatowitsch SM, van der Valk AG (1996) The vegetation of restored and natural prairie wetlands. Ecol Appl 6:102-112

González E, Masip A, Tabacchi E, Poulin M (2017) Strategies to restore floodplain vegetation after abandonment of human activities. Restor Ecol 25:82-91

Hölzel N, Otte A (2004) Assessing soil seed bank persistence in flood-meadows: the search for reliable traits. J Veg Sci 15:93-100

Kameyama Y, Ohara M (2007) Population genetic consequences of predominant clonal reproduction in free-floating aquatic bladderworts. Jpn J Ecol 57:245-250

Klimkowska A, Kotowski W, Van Diggelen R, Grootjans AP, Dzierz̈a P, Brzezińska K (2010) Vegetation re-development after fen meadow restoration by topsoil removal and hay transfer. Restor Ecol 18:924-933

Kuemmerle T, Hostert P, Radeloff VC, van der Linden S, Perzanowski K, Kruhlov I (2008) Crossborder comparison of post-socialist farmland abandonment in the carpathians. Ecosystems 11:614

Kuroyanagi A, Morimoto J, Shida Y, Shinsho H, Yabe K, Nakamura F (2019) Recovery of wetland vegetation in the Maizuru flood-retarding basin in the Chitose River watershed. J Jpn Soc Reveg Technol 45:45-50 
Middleton BA (2003) Soil seed banks and the potential restoration of forested wetlands after farming. J Appl Ecol 40:1025-1034

Mikulyuk A, Nault ME (2009) Water chestnut (Trapa natans): a technical review of distribution, ecology, impacts, and management. Wisconsin Department of Natural Resources Bureau of Science Services, Madison, WI

Morimoto J, Shibata M (2018) Vegetation succession on fallow land. In: Nakamura F (ed) Biodiversity conservation using umbrella species: Blakiston's fish owl and the red-crowned crane. Springer Singapore, Singapore, pp 197-206

Morimoto J, Shibata M, Shida Y, Nakamura F (2017) Wetland restoration by natural succession in abandoned pastures with a degraded soil seed bank. Restor Ecol 25:1005-1014

Nakamura F, Ishiyama N, Yamanaka S, Higa M, Akasaka T, Kobayashi Y, Ono S, Fuke N, Kitazawa M, Morimoto J, Shoji Y (2020) Adaptation to climate change and conservation of biodiversity using green infrastructure. River Res Appl 36:921-933

Oga I (1951) The longevity of seeds - my dream - my longing - excavation of old lotus seeds in the Kemigawa Peatland, Chiba Prefecture. Collect Breed 13:206-207

Phartyal SS, Rosbakh S, Poschlod P (2018) Seed germination ecology in Trapa natans L., a widely distributed freshwater macrophyte. Aquat Bot 147:18-23

Sheldon CJ, Ficklin RL, Fawley KP, Fawley MW, Bataineh M, Nelson AS, Wilson S (2016) Vegetation diversity in natural and restored forested wetland sites in Southeast Arkansas. J Ark Acad Sci 70:37

Toyoshima G, Morimoto J, Nakamura F (2020) The role of waterways in agricultural land landscapes in preserving the diversity of aquatic and epiphytes. J Jpn Green Eng Soc 46:15-20

Tsubota H, Inoue Y, Nakahara-Tsubota M, Shimamoto T, Matsuda I, Uchida S, Mukai S (2014) Combination of DNA barcoding and molecular phylogenetic analysis as an identification tool for plant species: a case study using imperfect herbarium specimens. Hikobia 16:475-490

Vécrin MP, Diggelen R, Grévilliot F, Muller S (2002) Restoration of species-rich flood-plain meadows from abandoned arable fields in NE France. Appl Veg Sci 5:263-270

Verhagen R, Klooker J, Bakker JP, Diggelen R (2001) Restoration success of low-production plant communities on former agricultural soils after top-soil removal. Appl Veg Sci 4:75-82

Weiher E, Keddy PA (1995) The assembly of experimental wetland plant communities. Oikos 73:323-335

World Water Assessment Programme (2009) The United Nations World Water Development Report 3: Water in a Changing World. UNESCO, Paris; London: Earthscan

Zedler JB, Kercher S (2005) WETLAND RESOURCES: status, trends, ecosystem services, and restorability. Annu Rev Environ Resour 30:39-74

Open Access This chapter is licensed under the terms of the Creative Commons Attribution 4.0 International License (http://creativecommons.org/licenses/by/4.0/), which permits use, sharing, adaptation, distribution and reproduction in any medium or format, as long as you give appropriate credit to the original author(s) and the source, provide a link to the Creative Commons license and indicate if changes were made.

The images or other third party material in this chapter are included in the chapter's Creative Commons license, unless indicated otherwise in a credit line to the material. If material is not included in the chapter's Creative Commons license and your intended use is not permitted by statutory regulation or exceeds the permitted use, you will need to obtain permission directly from the copyright holder. 